\title{
PENENTUAN ARAH KIBLAT MENURUT SHEIKH TAHIR JALALUDDIN DALAM KITABNYA PATI KIRAAN PADA MENENTUKAN WAKTU YANG LIMA DAN HALA KIBLAT DENGAN LOGARITMA
}

\section{The Determination of Qiblah by Sheikh Tahir Jalaluddin in His Book Pati Kiraan Pada Menentukan Waktu Yang Lima dan Hala Kiblat dengan Logaritma}

\author{
Siti Rahimah Mohammad Ikhsan* \\ Nurulhuda Ahmad Zaki** \\ Abdul Karim Ali ${ }^{* * *}$
}

\begin{abstract}
Sheikh Tahir Jalaluddin is a Malay scholar who introduced the logarithmic method to determine the Qiblah. There are three logarithmic methods recorded in his book, Pati Kiraan. Sheikh Tahir mentions that the Qiblah calculation in the logarithmic method is relatively easier than the previous method of 'ilm almiqat since the logarithmic method uses the 'sistem persepuluhan' (decimal system). Whereas, the 'ilm al-miqat method uses the 'sistem perenampulahan' (sexagesimal system). Although the method for the
\end{abstract}

* Master Candidate, Islamic Astronomy Programme, Department of Fiqh and Usul, Academy of Islamic Studies, University of Malaya, 50603 Kuala Lumpur. tubiatunmae@gmail.com

** Senior Lecturer, Islamic Astronomy Programme, Department of Fiqh and Usul, Academy of Islamic Studies, University of Malaya, 50603 Kuala Lumpur. zafran@um.edu.my

*** Associate Professor, Department of Fiqh and Usul, Academy of Islamic Studies, University of Malaya, 50603 Kuala Lumpur. abdkarim@um.edu.my 
determination of Qiblah using logarithm is easier, these three methods of Sheikh Tahir Jalaluddin have not yet been tested for their accuracy. Furthermore, previous studies have found that the methods are less accurate than the modern approach for determining the Qiblah. Thus, this study endeavors to analyze the accuracy of the three logarithmic methods in determining the direction of Qiblah. This study uses library resources for collecting the data and analyzes the data using comparative methodology. The results found that the calculation error in Sheikh Tahir's logarithmic method is around one degree. The value is still can be accepted as it is an ijtihadi and zanni. The methods therefore can be used as a reference in determining the direction of Qiblah in Malaysia and it still can be benifited by Muslim astronomers to acknowledge Sheikh Tahir Jalaluddin's pioneer services of modern methods in determining the direction of the Qiblah in Malaysia.

Keywords: Sheikh Tahir, Pati Kiraan, Qiblah direction, logarithmic

\section{PENDAHULUAN}

Penyebaran Islam di Tanah Melayu telah meninggalkan banyak khazanah ilmu kepada masyarakat Melayu. Penghijrahan tokohtokoh agama Melayu ke Tanah Arab ${ }^{1}$ untuk menuntut ilmu juga telah menyebabkan ilmu falak berkembang di Alam Melayu. Ilmu falak di Alam Melayu dipelajari oleh tokoh-tokoh agama kerana ia merupakan ilmu yang penting yang diperlukan untuk tujuan pengamalan ibadah.

Ilmu falak ataupun ilmu astronomi ialah ilmu yang digelar sebagai queen of science yang merangkumi bidang matematik, mekanik samawi dan fizik khususnya dalam bidang optik. ${ }^{2}$ Ilmu

\footnotetext{
1 Zainal, Baharrudin, "Grafiti Falak Rumpun Melayu Melalui Kajian Teks Utama," Menemui Matematik, vol. 32 (2010), 57.

2 Ilyas, Mohammad, Astronomi Islam dan Perkembangan Sains: Kegemilangan Masa Lalu Cabaran Masa Depan (Kuala Lumpur: Institut Terjemahan Negara Malaysia Berhad, 2003), 17.
} 
ini menjadi sangat penting dalam Islam kerana ia berkaitan dengan hal ibadah kepada umat Islam. ${ }^{3}$ Salah satunya adalah berkenaan ibadah solat. Ibadah solat merupakan salah satu daripada rukun Islam. Umat Islam menunaikan solat sebanyak lima kali dalam sehari. Menghadap kiblat merupakan salah satu daripada syarat sah solat. Perintah untuk menghadap kiblat terdapat di dalam alQuran sebagaimana berikut:

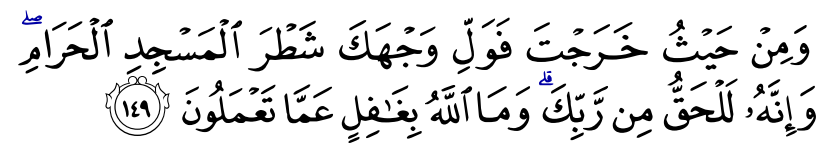

Terjemahan: "Dan dari mana sahaja engkau keluar (untuk mengerjakan sembahyang), maka hadapkanlah mukamu ke arah Masjidilharam (Kaabah); dan Sesungguhnya perintah berkiblat ke Kaabah itu adalah benar dari Tuhanmu. dan (ingatlah), Allah tidak sekali-kali lalai akan segala apa yang kamu lakukan.'

(Surah al-Baqarah, 2: 149)

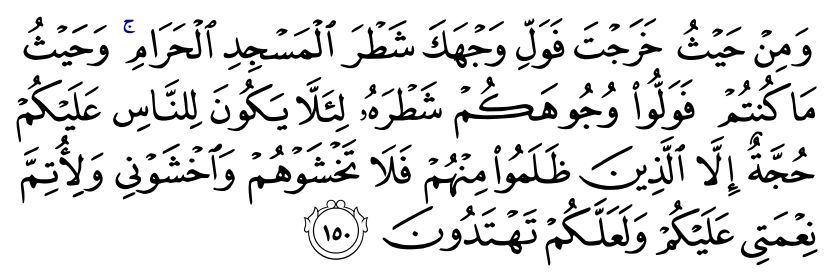

Terjemahan: "Dan dari mana sahaja engkau keluar (untuk mengerjakan sembahyang), maka hadapkanlah mukamu ke arah Masjidilharam (Kaabah); dan di mana sahaja kamu berada maka hadapkanlah muka kamu ke arahnya, supaya tidak ada lagi (sebarang) alasan bagi orang-orang (yang menyalahi kamu), kecuali orang-orang yang zalim di antara mereka (ada sahaja yang mereka jadikan

Saadan Man, Mohd Zambri Zainuddin, Mohd Roslan Mohd Nor, Mohd Anuar Ramli, Rahimin Affandi Abdul Rahim, Rushdi Ramli \& Ridzwan Ahmad, "The Development of Islamic Astronomy Studies in Higher Learning Institution in Malaysia," Middle-East Journal of Scientific Research, vol. 12, no. 1 (2012), 1. 
alasan). maka janganlah kamu takut kepada (cacat cela) mereka, dan takutlah kamu kepadaKu (sematamata); dan supaya Aku sempurnakan nikmatKu kepada kamu, dan juga supaya kamu beroleh petunjuk hidayah (mengenai perkara yang benar)."

(Surah al-Baqarah, 2: 150)

Arah kiblat ialah arah menghadap Kaabah yang berada di Mekah. Bagi umat Islam yang tinggal di sekitar kawasan Kaabah atau di sekitar kawasan Masjidilharam, adalah mudah bagi mereka untuk menghadap kiblat kerana Kaabah berada hampir dengan mereka. Namun, bagi umat Islam yang berada jauh dari Kaabah, contohnya di Malaysia, maka penentuan arah kiblat bukanlah sesuatu yang mudah untuk dilakukan. Dalam kes ini, ulama dari empat mazhab iaitu, mazhab Ḥanafì, Mālikī, Shāfi ‘̄i dan Ḥanbalī berbeza pandangan tentang arah kiblat bagi umat Islam di luar kota Mekah.

Umat Islam yang berada di dalam kawasan Masjidilharam sama ada dapat melihat Kaabah atau tidak, mereka wajib menghadap ke arah kaabah dengan yakin. Keyakinan itu dapat diperolehi dengan cara melihat ataupun dengan cara menyentuhnya bagi yang buta atau cara lain yang boleh menimbulkan keyakinan tersebut. Kiblat ini dinamakan sebagai "Kiblat Yakin". ${ }^{4}$ Bagi umat Islam yang berada di luar Masjidilharam yakni jauh daripada Kaabah maka hendaklah menghadapkan diri ke arah kiblat secara zanni ataupun menurut ijtihadnya. Cara untuk mengetahui arah kiblat melalui kaedah ini adalah melalui kaedah bertanya kepada orang yang mengetahui arah kiblat tersebut sebagai contoh penduduk Mekah. Kiblat ini dinamakan sebagai "kiblat zanni".

Umat Islam yang berada di luar Masjidilharam atau di luar Kota Mekah hendaklah menghadap ke arah Tanah Suci (Mekah) dengan niat untuk menghadap ke arah kiblat. Ia memadai untuk menunaikan kehendak syarak bagi menunaikan solat. ${ }^{5}$ Oleh kerana

$4 \quad$ Abū 'Abd Allāh Muhammad bin Idris al-Shāfi'ī, , "al-Umm”, laman sesawang al-Maktabah al-Shämilah, http://shamela.ws/browse.php/ book-1655\#page-99, dicapai pada 16 Januari 2018.

5 Unit Falak, Bahagian Penyelidikan, Jabatan Kemajuan Islam Malaysia, Kaedah Panduan Falak Syarie (Kuala Lumpur: JAKIM, 2001), 4-5. 
telah berlaku perkembangan intelektual manusia umumnya, dan umat Islam khususnya, wujud pelbagai kaedah moden yang mampu untuk mengukur arah kiblat walaupun pada jarak yang jauh. Umat Islam telah melakukan ijtihad penentuan arah kiblat menggunakan peralatan moden, juga berdasarkan kepada perhitungan falak. Ia adalah satu usaha untuk memudahkan memudahkan umat Islam dalam melaksanakan tuntutan ibadah solat.

Pada masa kini, banyak kajian telah dilakukan dalam aspek kaedah penentuan arah kiblat sejak abad ke-18 Masihi hingga kini. Pelbagai penulisan manuskrip dan naskah Alam Melayu dijumpai oleh para pengkaji. ${ }^{6}$ Manuskrip-manuskrip dan naskahnaskah Alam Melayu ini sewajarnya mendapat perhatian ahli-ahli akademi untuk mengkajinya. Kajian teks dan manuskrip Melayu lama adalah sangat penting kerana manfaat ilmu yang bakal diperoleh daripadanya. Namun begitu, ia masih kurang mendapat perhatian untuk dikaji. Kelemahan ini menyebabkan warisan keilmuan tersebut tidak mengalir dan kesannya masyarakat Melayu sendiri tidak mengetahui dan tidak mampu untuk menghargainya. Jika ada, ia lebih dilihat sebagai bahan pameran untuk tontonan umum sahaja.

Di Malaysia, terdapat banyak manuskrip dan naskah yang membincangkan tentang penentuan arah kiblat dalam bentuk formula yang berbeza daripada kaedah moden. Baharrudin Zainal telah menyenaraikan 60 manuskrip dan naskhah falak. Senarai ini diperolehi hasil daripada pengumpulan oleh Kumpulan Penyelidikan Matematik Melayu (KuPELEMA). ${ }^{7}$ Antara naskhah falak yang berjaya dikumpulkan ialah naskah yang ditulis oleh Syeikh Tahir Jalaluddin iaitu kitab Nukhbat al-Taqrīrāt fi Hisāb al-Waqt wa al-Samt Qiblah bi al-Lughāritmāt (1365 H/ 1937 M) dan kitab Pati Kiraan Pada Menentukan Waktu Yang Lima dan Hala Kiblat Dengan Logaritma (1357 H/ 1938 M). Kedua-dua kitab tersebut merupakan kitab yang ada membincangkan secara terperinci tentang kaedah penentuan arah kiblat.

Dalam menelusuri kitab Pati Kiraan, penulis dapati terdapat tiga kaedah menghitung arah kiblat menggunakan logaritma. Kaedah-kaedah yang terdapat dalam kitab tersebut berbeza

6 Zainal, Baharrudin, Pentahkikan Naskhah Falak Alam Melayu (Selangor: Jabatan Mufti Negeri Selangor, 2016), 4-8.

7 Zainal, Baharrudin, Pentahkikan Naskhah Falak Alam Melayu, 4. 
operasinya. Maka hasil hitungan juga adalah berbeza. Oleh demikian, penulis menelusuri persoalan sejauh manakah ketepatan ketiga-tiga kaedah tersebut? Dalam kajian ini, ketiga-tiga kaedah tersebut diuji ketepatannya secara perbandingan dengan kaedah moden. Setiap satu kaedah juga dikaji dalam aspek kelemahan dan ketepatannya. Akhir sekali analisis terhadap perbezaan kesemua kaedah tersebut dikemukakan untuk mendapatkan hasil kajian yang dikehendaki.

\section{TINJAUAN PUSTAKA}

Kajian lepas merujuk kepada beberapa kajian yang telah dilakukan oleh para pengkaji terdahulu bagi mendapatkan maklumat kajian. Oleh yang demikian, kajian ini telah dibahagikan kepada tiga tema utama iaitu kajian berkenaan keperibadian Sheikh Tahir, ketokohan beliau dalam bidang falak dan akhir sekali berkenaan kajian terhadap kitab Pati Kiraan beliau yang khusus membincangkan kaedah penentuan arah kiblat menggunakan logaritma.

Berdasarkan kajian lepas, ramai pengkaji mengaitkan Sheikh Tahir dengan gelaran tokoh pembaharuan. Ia dibuktian berdasarkan tulisan Kamaruddin Salleh Mohamad Amin (2011), Bachtiar Djamily (1994), Sarim Mustajab (2005), Hafiz Zakaria (2006), Azyumardi Azra (1996) dan sebagainya. Antara penulis yang melakukan kajian khusus terhadap riwayat hidup beliau adalah Bachtiar Djamily (1994), Hafiz Zakaria (2006) dan Mafri Amir (2008). Azyumardi Azra (1996) pula dalam tulisannya menceritakan tentang pengaruh Sheikh Tahir dalam perubahan politik Islam di dunia Melayu. Pengaruh gerakan pembaharuan beliau begitu besar dan memberi pengaruh terhadap perkembangan Islam di dunia Melayu-Indonesia.

Pengkaji lepas telah menyatakan bahawa Sheikh Tahir adalah seorang revolusioner $^{8}$ yang bermaksud pembawa idea-idea

8 Mustajab, Sarim, "Sheikh Tahir Jalaluddin al-Falaki," (Kertas Kerja, Seminar Keilmuan Falak Sheikh Tahir Jalaluddin dan Sheikh Abdullah Fahim: Perintis Ilmu Falak Moden, Pulau Pinang, 2005), 15. 
baru. ${ }^{9}$ Selain itu beliau dipercayai menerima pengaruh tajdidnya daripada Sheikh Muhammad Rashid Rida yang merupakan anak murid kepada Sheikh Muhammad Abduh. Pengaruh tersebut diperolehinya ketika mana beliau melanjutkan pelajarannya di Mesir. ${ }^{10}$ Sheikh Tahir adalah ulama yang sangat tegas dalam mempertahankan sesuatu pendapat dan sangat pantang jika sesuatu amalan ibadah dilakukan hanya berdasarkan taklid buta ${ }^{11}$ tanpa ada dalil yang kukuh. ${ }^{2}$

Banyak pertentangan yang berlaku antara Kaum Muda yang dipeloporinya dengan Kaum Tua ${ }^{13}$ yang lebih bersifat tradisionalis berkenaan perkara khilafiah ${ }^{14}$ ataupun cabang dalam agama. ${ }^{15}$ Antara isu-isu tersebut adalah seperti mempertikaikan kesahihan hadis tertentu, pembayaran upah pengebumian, amalan tertentu yang berkaitan tentang tarekat, pemakaian pakaian Eropah dan sebagainya. ${ }^{16}$ Selain dalam bidang fiqh dan isu-isu hukum, Sheikh Tahir juga popular sebagai ulama falak. Ketokohan beliau telah mendapat pengiktirafan semasa hayat beliau lagi. Beliau mendapat kepercayaan untuk memeriksa arah kiblat masjid dan surau oleh

9 Laman sesawang Pusat Rujukan dan Persuratan Melayu, dicapai pada 2 November 2018, http://prpm.dbp.gov.my/ Caril?keyword $=$ revolusioner.

10 Zakariyya, Hafiz, "The Life and Times of Tahir Jalaluddin," Jurnal Sejarah, vol. 14 (2006), 99.

11 Hanya menurut saja tanpa berfikir, laman sesawang Pusat Rujukan dan Persuratan Melayu, dicapai pada 2 November 2018, http://prpm. dbp.gov.my/Caril?keyword=revolusioner.

12 Zakariyya, Hafiz, "Islamic Reform in Malaya: The Contribution of Shayk Tahir Jalaluddin," Intellectual Discourse, vol. 13, no. 5 (2005), 53.

13 Azra, Azyumardi, "The Transmission of al-Manar's Reformism to The Malay-Indonesia World: The Cases of al-Imam and al-Munir," Studia Islamika, vol. 6, no. 3 (1999), 85.

14 Yang tidak mempunyai dalil yang tepat mengenai hukumannya, laman sesawang Pusat Rujukan dan Persuratan Melayu, dicapai pada 2 November 2018, http://prpm.dbp.gov.my/Cari1?keyword=khilafiah.

15 Salleh, Kamaruddin, "Transformasi Pemikiran Pembaharuan dan Modenisme di Malaysia: Satu Penelitian Awal," International Journal of Islamic Thought (2012), 23-37.

16 Azra, Azyumardi, "The Transmission of al-Manar's Reformism to The Malay-Indonesia World: The Cases of al-Imam and al-Munir," 75-100. 
Sultan Idris di seluruh negeri Perak semasa hayatnya. ${ }^{17}$ Malah menurut Susiknan, Sheikh Tahir telah menyebarkan ilmu falak di nusantara meliputi alam Melayu dan Indonesia. Sumbangan tersebut dapat dilihat dari hasil penulisan falak beliau yang banyak. ${ }^{18}$

Antara penulis yang mengkaji tentang penulisan beliau adalah seperti Baharrudin Zainal (2016), Ahmad Faisal Abdul Hamid (2017), Noorzahidah Mohd Zain (2014), Siti Muslifah (2013) dan Mahya Laila (2011). Baharrudin Zainal adalah salah seorang pengkaji yang banyak menulis tentang penulisan falak Sheikh Tahir. Penulisan beliau sehingga ke hari ini masih dikaji kerana sumbangannya yang besar. Untuk mengenang jasa beliau terhadap penyebaran ilmu falak ini, kerajaan Pulau Pinang telah mendirikan balai cerap yang dinamakan sebagai Pusat Falak Syeikh Tahir. Satu-satu keistimewaan yang ada pada Sheikh Tahir adalah beliau adalah ulama yang pertama menggabungkan unsur falak moden dan tradisional iaitu dengan menggabungkan teknik deskriptif dan kuantitatif. ${ }^{19}$ Ilyas juga telah menyatakan bahawa Sheikh Tahir adalah bapa astronomi Islam Malaysia. ${ }^{20}$

Kajian khusus terhadap kitab Pati Kiraan karya Sheikh Tahir tidak terlalu mendapat perhatian sebagaimana naskhah beliau yang lain yang berkaitan dengan hukum fikah. Ini dapat dibuktikan berdasarkan jumlah penulisan yang membincangkan tentang kitab tersebut. Hanya terdapat tiga orang pengkaji sahaja yang mengkaji tentang kitab Pati Kiraan iaitu Baharrudin Zainal (2016), Mahya Laila (2011) dan Siti Muslifah (2013). Kajian yang berkaitan

17 Mustajab, Sarim, "Syeikh Muhammad Tahir Jalaluddin al-Falaki, Pelopor Gerakan Islah Islamiyyah di Tanah Melayu," Malaysian in History, vol. 20, no. 23 (1977), 3.

18 Azhari, Susiknan, "Perkembangan Kajian Astronomi Islam di Alam Melayu," Jurnal Fiqh (2010), 167-184.

19 Mohamad Amin Abu Bakar, "Sumbangan Syeikh Tahir Jalaluddin (1860-1965) terhadap Perkembangan Fiqh di Nusantara," (makalah, Prosiding Nadwah Ulama Nusantara (NUN) IV: Ulama Pemacu Transformasi Negara, Jabatan Pengajian Arab dan Tamadun Islam, Fakulti Pengajian Islam, Universiti Kebangsaan Malaysia, 25-26 November 2011), 272.

20 Zakariya, Hafiz, "Colonialism, Society and Reforms in Malaya: A Comparative Evaluation of Shaykh Tahir Jalaluddin and Syed Shaykh Ahmad al-Hady," Intellectual Discourse (2017), 483. 
tentang penentuan arah kiblat sahaja hanya dilakukan oleh Mahya Laila (2011). Namun begitu, kajian beliau hanya menyentuh satu kaedah penentuan arah kiblat dan mengabaikan kaedah yang lain.

Dalam pada itu, Baharrudin (2016) menyatakan bahawa kitab Pati Kiraan ini adalah merupakan manuskrip Melayu teragung kerana penggunaan kaedah logaritma dalam penentuan waktu solat dan arah kiblat. Baharrudin Zainal juga adalah penulis yang paling menonjol dalam kajian kitab Pati Kiraan. Namun begitu, kajian beliau lebih bertumpu kepada rumusan dan ringkasan terhadap naskhah tersebut. Baharrudin Zainal tidak menyatakan apa-apa isu berkaitan kitab tersebut. Terdapat dua kajian lain yang telah menimbulkan beberapa isu dalam kitab Pati Kiraan. Isu tersebut adalah berkaitan ketepatan kiraan kaedah Sheikh Tahir jika dibandingkan dengan kaedah-kaedah lain.

Mahya Laila di dalam kajiannya menyatakan bahawa kitab Pati Kiraan kurang tepat dalam menentukan hala kiblat berbanding kitab Khulasah al-Wafiyyah. Beliau juga telah menyarankan supaya menggunakan kaedah yang lebih tepat bagi menentukan arah kiblat kerana ia bersangkutan dengan sah dan tidaknya solat yang menjadi kewajipan bagi semua orang Islam. ${ }^{21}$

Menurut Siti Muslifah dalam kajiannya telah menyatakan bahawa Sheikh Tahir Jalaluddin al-Minangkabawi merupakan ahli falak yang pertama ${ }^{22}$ memperkenalkan kaedah hitungan moden. Namun begitu, hasil kajian yang telah dijalankan terhadap ketepatan kaedah pengiraan menunjukkan bahawa kaedah Sheikh Tahir menghasilkan jawapan yang berbeza dengan kaedah yang digunakan sekarang. Muslifah telah menyimpulkan bahawa kaedah yang digunapakai Sheikh Tahir dipengaruhi oleh kaedah guru-gurunya. Penentuan waktu solat dalam kitab Pati Kiraan

21 Laila Mahya, "Studi Komparasi Tentang Keakurasian Hisab Arah Kiblat Menurut Syekh Muhammad Thahir Jalaluddin alMinangkabawi dalam Kitab Pati Kiraan Pada Menentukan Waktu Yang Lima dan Hala Kiblat dengan Logaritma dan K.H Zubair Umar al-Jailani dalam Kitab al-Khulasah al-Wafiyyah,” (Latihan Ilmiah, Sarjana Muda, IAIN Walisongo, Semarang, 2011).

22 Siti Muslifah, "Analisis Pemikiran Syeikh Muhammad Tahir Jalaluddin al-Minangkabawi Tentang Penentuan Waktu Salat dalam Kitab Pati Kiraan dan Akurasinya" (Disertasi Sarjana, Institut Agama Islam Negeri (IAIN) Walisongo, 2013), 1. 
berlaku kerana terpengaruh dengan waktu zuhur yang diambil daripada minit Soekatan Masa yang telah ditetapkan Sheikh Tahir. Jika minit Soekatan Masa ini diubah, penentuan waktu solat akan menghasilkan data yang lebih tepat.

Berdasarkan kajian-kajian lepas yang telah ditunjukkan di atas, masih kurang pengkaji yang menyelidik tentang ketepatan kitab Pati Kiraan secara menyeluruh dan terperinci. Malah tiada lagi kajian yang menelusuri ketepatan untuk ketiga-tiga kaedah yang terdapat dalam kitab Pati Kiraan. Kajian lepas lebih banyak tertumpu kepada ketepatan sebahagian kaedah sahaja dan menghuraikan ringkasan terhadap terhadap keseluruhan isi kandungan kitab Pati Kiraan. Oleh yang demikian, kajian ini dijalankan bagi melengkapkan kajian-kajian yang sebelum ini.

\section{KITAB PATI KIRAAN}

Kitab Pati Kiraan Pada Menentukan Waktu Yang Lima dan Hala Kiblat dengan Logaritma adalah kitab yang telah ditulis oleh Sheikh Tahir Jalaluddin al-Falaki pada tahun 1937M. Pada asalnya kitab ini merupakan kitab berbahasa Arab. Nama kitab tersebut ialah, Nukhbah al-Taqrīrāh fì Hisāb al-Awqāt wa al-Samt al-Qiblat bi al-Loghāritmāt. Kitab Arab tersebut kemudiannya telah diterjemahkan oleh beliau dan ditashihkan hasil terjemahan tersebut oleh pakar bahasa yang bernama al-Fādil al-Najīb Zainal Abidin Ahmad iaitu Pendeta Za' ba. ${ }^{23}$ Terdapat bukti surat menyurat diantara Sheikh Tahir dan Pendeta Za'ba yang membicarakan tentang urusan penyemakan penterjemahan yang dilakukan oleh Pendeta Za'ba. ${ }^{24} \mathrm{Za}$ 'ba juga sebenarnya merupakan salah seorang daripada anak murid Sheikh Tahir Jalaluddin. ${ }^{25}$

Justifikasi untuk tidak memilih teks asal dalam bahasa Arab adalah kerana ia telah mengalami beberapa perubahan setelah berlaku perterjemahan. Memandangkan kitab Pati Kiraan adalah kitab yang dicetak lebih terkemudian dari kitab asal Arabnya,

23 Zainal, Baharrudin, Pentahkikan Naskhah Falak Alam Melayu, 44.

24 SP 10 622/36, No. Penerimaan: (2006/0036258), Surat dari Za'ba Kepada Sheikh Tahir Mengenai Terjemahan Kitab Sheikh Tahir, 27 September 1937.

25 No. Penerimaan: (2006/0046405), Ringkasan Riwayat Hidup Zaaba, Arkib Negara Malaysia; Kuala Lumpur. 
maka lebih layaklah ia dipilih berdasarkan kriteria maklumat dan data yang lebih terkini yang telah diperbetulkan serta disemak semula oleh penulisnya demi memberi kefahaman yang lebih mendalam kepada para pembacanya. Pengkaji telah melakukan semakan dan perbandingan terhadap kedua-dua kitab tersebut untuk mengenal pasti adakah isi kandungan di dalamnya masih sama atau tidak. Ternyata, majoriti isi kandungannya adalah sama melainkan beberapa pindaan dan tambahan maklumat yang tidak mengubah maksud dan kaedah yang terdapat di dalam kitab versi Arab. ${ }^{26}$

Namun begitu, kitab asal yang berbahasa Arab tidak boleh dilupakan begitu sahaja. Kitab Arab tersebut tetap dirujuk jika muncul kekeliruan yang terdapat dalam kitab Pati Kiraan. Sheikh Tahir telah menyatakan kaedah yang beliau persembahkan dalam kitab ini adalah hasil daripada pembelajarannya ketika berada di Mesir. Beliau ada menyebutkan nama gurunya yang telah mengajarkan beliau kaedah tersebut iaitu "orang alim yang semasyhur-masyhurnya pada ilmu mīqāt" iaitu Sheikh Muhammad Abī al-Faḍl. Kaedah tersebut adalah dengan menggunakan kaedah logaritma.

Pengkaji telah menganalisis kaedah penentuan arah kiblat dalam Pati Kiraan. Analisis dilakukan dengan menghuraikan kaedah penentuan arah kiblat tersebut menggunakan singkatan rumus dan melakukan perbandingan hasil kiraan kaedah yang terdapat dalam Pati Kiraan dengan kaedah moden. Pengkaji akan menghuraikan ketiga-tiga kaedah dalam Pati Kiraan tersebut satu demi satu terlebih dahulu menggunakan singkatan rumus dan kemudian melakukan analisis perbandingan kaedah tersebut dengan kaedah moden

\section{KAEDAH LOGARITMA DALAM KITAB PATI KIRAAN}

Terdapat tiga kaedah penentuan arah yang terdapat dalam kitab Pati Kiraan. Kaedah pertama dinamakan sebagai kaedah Riḍwan

26 Sila rujuk kandungan yang terdapat dalam kitab Pati Kiraan pada tajuk "Huraian Yangkedua Pada Menyatakan Tūl Matahari dan Mayl nya dan Ghāyah Irtifā'nya dan Ard Negeri dan Tūlnya” di halaman 5 hingga halaman 9 dan bandingkan dengan kandungan yang terdapat dalam kitab Nukhbat al-Taqrīrat di halaman 4. 
Afandī, kaedah kedua pula dinamakan sebagai kaedah Abī al-Faḍl dan yang terakhir pula adalah kaedah pelayaran ataupun kaedah al-Bahrīyyah.

\section{Kaedah Pertama; Kaedah Riḍwan Afandī}

Berdasarkan pengakuan Sheikh Tahir di dalam kitabnya, beliau menyatakan bahawa kaedah pertama ini adalah kaedah yang diperolehinya daripada $z \bar{l} j^{27}$ almarhum Riḍwān Afandī. Berkenaan peribadi tokoh ini tidak dinyatakan pula oleh Sheikh Tahir secara lebih terperinci melainkan hanya seperti berikut:

“...bin Abdullah iaitu seorang yang 'alim yang muhaqqiq dalam ilmu al-hisāb dan ilmu falak ialah yang mengarang al-zīj (kitab kira-kira perjalanan bintang-bintang al-sayyārah) daripada punca hintaian baharu akan gerakan bintang-bintang bagi Ulugh Beg al-Samarqandī, wafatnya pada bulan Rejab tahun 1122 Hijrah alaihi al-rahmah wa alriḍwān." 28

Selain itu, Sheikh Tahir juga mengatakan bahawa $z \bar{i} j$ ini merupakan jadual yang bertulis tangan. Namun begitu, beliau telah menyatakan rasa kecewa dan dukacitanya terhadap $z \bar{i} j$ ini kerana terdapat banyak kesalahan di dalamnya. Punca terhadap kesalahan itu menurutnya adalah mungkin kerana semasa proses penyalinan semula $z \hat{i} j$ tersebut telah berlaku kesalahan mencatat sama ada dengan berlakunya penambahan atau pengurangan perkataan. ${ }^{29}$ Kaedah pertama ini adalah kaedah yang berasaskan kepada formula segitiga sfera berdasarkan kaedah sinus (juyūb) yang diaplikasikan di dalam penggunaan jadual logaritma. Baharrudin Zainal telah melakukan penyesuaian rumus kaedah ini seperti berikut: ${ }^{30}$

$$
\operatorname{Sin} \theta=\sin \Delta \lambda /(\sin p) \sin \left(90^{\circ}-\varphi m\right)
$$

27 Jadual falak/ephemeris, laman sesawang Kamus al-Maany, dicapai 1 Oktober 2018, https://www.almaany.com/en/dict/aren $/ \% \mathrm{D} 8 \% \mathrm{~B} 2 \% \mathrm{D} \% \% 8 \mathrm{~A} \% \mathrm{D} 8 \% \mathrm{AC} /$

28 Sheikh Tahir, Pati Kiraan, 24.

29 Sheikh Tahir, Pati Kiraan, 24.

30 Baharrudin Zainal, Ulasan Karya Falak Sheikh Tahir Jalaluddin, 14. 
Secara keseluruhannya, kaedah pertama ini berkaitan tentang penjelasan kedudukan kawasan yang ingin dicari arah kiblat daripada Mekah. Sheikh Tahir telah melakukan pengelasan terhadap kedudukan kawasan dengan Mekah kepada lima bahagian kes seperti dalam jadual 1 di bawah.

\section{Jadual 1: Pengelasan kedudukan kawasan yang dihitung dengan kedudukan Mekah}

\begin{tabular}{|c|c|}
\hline Bil. & Pengelasan \\
\hline Kes 1 & $\Lambda$ Timur nilainya sama dengan $K$ Mekah \\
\hline Kes 2 & $\begin{array}{l}\text { Beza antara } \Lambda \text { Mekah dan } \Lambda \text { kawasan hitungan adalah } \\
<90^{\circ}\end{array}$ \\
\hline Kes 3 & Beza antara $K$ Mekah dan $K$ kawasan $=90^{\circ}$ \\
\hline Kes 4 & $\begin{array}{l}\text { Beza antara } K \text { Mekah dan } K \text { kawasan yang dikira }>90^{\circ} \\
\text { namun }<180^{\circ}\end{array}$ \\
\hline Kes 5 & $\begin{array}{l}\text { Beza antara } K \text { Mekah dan } K \text { kawasan yang dikira }= \\
180^{\circ}\end{array}$ \\
\hline
\end{tabular}

\section{Kes 1: $\boldsymbol{\Lambda}$ Timur nilainya sama dengan $\boldsymbol{\Lambda}$ Mekah}

a) Arah kiblat mengadap utara:

Vologda Oblast, Russia (59 $9^{\circ} 12^{\prime} 52.01$ 'U; $\left.39^{\circ} 52^{\prime} 55.16^{\prime \prime} \mathrm{T}\right)$ (Google Maps, 2018).

Kedudukan Vologda, Russia terletak di kedudukan latitud melebihi latitud Mekah. Maka arah kiblatnya menghadap ke utara.

b) Arah kiblat mengadap selatan:

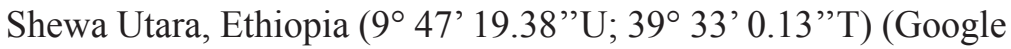
Maps)

Kedudukan Shewa Utara terletak di kedudukan latitud kurang daripada latitud Mekah. Maka arah kiblatnya menghadap ke arah selatan 


\section{Rajah 1: Kawasan Kiblat ke Arah Utara dan Selatan}

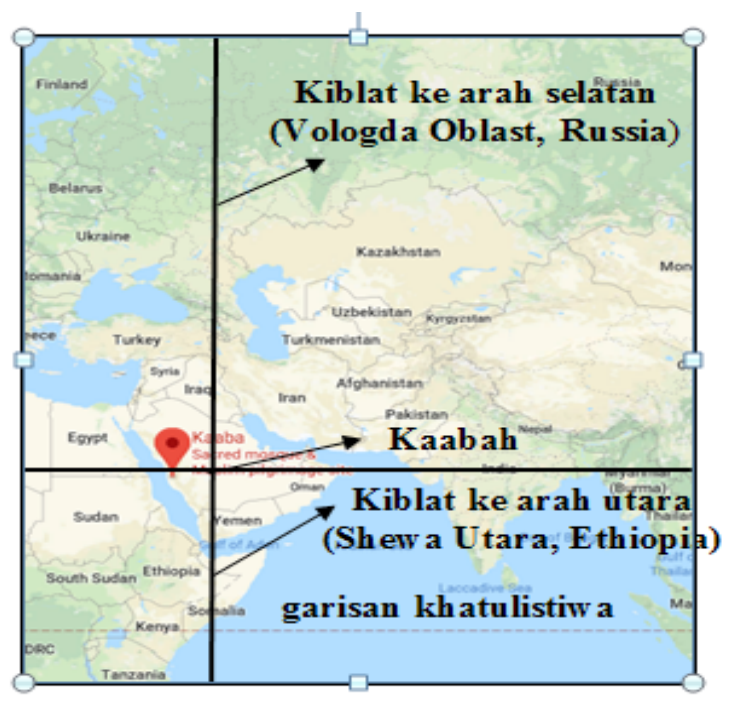

Dalam kes 1 di atas, kawasan kiraan berada di sebelah timur dan nilai longitudnya adalah sama dengan nilai longitud Mekah. Arah kiblat bagi kawasan tersebut boleh menghadap kearah utara atau selatan berdasarkan kedudukan kawasan dari Mekah. Kedudukan kawasan tersebut adalah sama ada latitud kawasan itu kurang dari latitud Mekah atau lebih. Jika latitud kawasan tersebut lebih daripada Mekah maka arah kiblatnya akan menghadap ke arah selatan manakala jika latitud kawasan kurang daripada latitud Mekah maka arah kiblat akan menghadap ke arah utara.

Kes 2: Beza antara $\kappa$ Mekah dan $\kappa$ kawasan hitungan adalah $<90^{\circ}$

Berikut adalah contoh-contoh kawasan yang memenuhi ciri-ciri kes 2: 
Penentuan Arah Kiblat Menurut Sheikh Tahir Jalaluddin dalam Kitabnya Pati Kiraan Pada Menentukan Waktu Yang Lima dan Hala Kiblat dengan Logaritma Jadual 2: Contoh kawasan yang memiliki beza antara
Longitud Mekah dan Longitud Kawasan $<90^{\circ} 31$

\begin{tabular}{|c|c|}
\hline Nama Tempat & Koordinat Kawasan \\
\hline Jakarta & $6^{\circ} 12^{\prime} 22.4^{\prime \prime} \mathrm{S} ; 106^{\circ} 50^{\prime} 47.3^{\prime \prime} \mathrm{T}$ \\
\hline Bukit Tinggi & $0^{\circ} 18^{\prime} 14.26^{\prime \prime} \mathrm{S} ; 100^{\circ} 23^{\prime} 1.15^{\prime \prime} \mathrm{T}$ \\
\hline Pulau Pinang & $5^{\circ} 24^{\prime} 35.83^{\prime \prime} \mathrm{U} ; 100^{\circ} 20^{\prime} 47.5^{\prime \prime}$ \\
\hline Singapura & $1^{\circ} 21^{\prime} 18.66^{\prime \prime} \mathrm{U} ; 103^{\circ} 52^{\prime} 18.2^{\prime \prime} \mathrm{T}$ \\
\hline Bangkok & $13^{\circ} 46^{\prime} 59.2^{\prime \prime} \mathrm{U} ; 100^{\circ} 28^{\prime} 45.4^{\prime \prime} \mathrm{T}$ \\
\hline Rio de Janeiro & 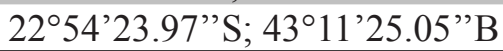 \\
\hline
\end{tabular}

Sumber: Google Maps, 2018

Pengiraan arah kiblat untuk kes ke dua adalah berdasarkan rumus berikut:

\section{Rumus hitungan untuk kes 2:}

$\log \sin \Delta \lambda+\log \sin \left(90^{\circ}-\varphi m\right)=A$

$\log \sin \left(90^{\circ}-\mathrm{A}\right)-\log \sin \varphi \mathrm{m}=\mathrm{B}$

$\mathrm{B}+\left(90^{\circ}-\varphi \mathrm{t}\right)=\mathrm{C}\left(* \mathrm{jika}<90^{\circ}\right)$

$180^{\circ}-\mathrm{B}=\mathrm{C}\left(* \mathrm{jika}>90^{\circ}\right)$

$\mathrm{B}-180^{\circ}=\mathrm{C}\left(* \mathrm{jika}>180^{\circ}\right)$

$\log \sin \left(90^{\circ}-\mathrm{A}\right)+\log \sin \mathrm{C}=\log \sin \mathrm{Q}$

$\mathrm{Q}=\log \sin \mathrm{Q} \rightarrow$ nilai sudut $\mathrm{Q}$

Nilai sudut $Q$ ialah sudut arah kiblat

Rumus di atas merupakan langkah-langkah untuk menghitung arah kiblat. Namun rumus ini hanya boleh digunakan untuk kes 2, di mana beza antara $\Lambda$ Mekah dan $K$ kawasan hitungan adalah $<90^{\circ}$. Kaedah asal di dalam kitab Pati Kiraan adalah dalam bentuk kualitatif dan huraiannya sangat panjang. Oleh itu, penulis meringkaskan dalam bentuk kuantitatif atau rumus untuk lebih difahami umum dan memudahkan proses hitungan. Untuk hitungan ini, Sheikh Tahir telah menggunakan istilah 'simpanan' bagi menyatakan hasil jumlah operasi bagi setiap langkah yang berlaku dalam pengiraan. Bagi memudahkan pembaca memahami kaedah pengiraan, pengkaji telah menggunakan istilah 'langkah'

31 Jalaluddin, Sheikh Tahir, Jadawil Nukhbat al-Taqrirah (Singapore: Sin Sheng Press, 1954), 14. Nilai longitud kawasan tersebut telah disesuaikan dengan nilai yang terdapat di google maps. 
sebagai ganti kepada istilah 'simpanan'. Contohnya, 'simpanan yang pertama' menjadi 'langkah pertama' yang disimbolkan sebagai A. ${ }^{32}$

\section{Kes 3: Beza antara $\Lambda$ Mekah dan $\Lambda$ kawasan $=90^{\circ}$}

Untuk kes ketiga ini, Sheikh Tahir menjelaskan contoh hitungan arah kiblat dalam 2 kategori. Kategori pertama ialah kawasan yang berada di atas garisan khatulistiwa di mana $\left(\varphi \mathrm{t}=0^{\circ}\right)$; nilai latitud $=$ $0^{\circ}$. Kawasan yang berada di latitud $0^{\circ}$ maka arah kiblatnya adalah sebanyak nilai pencukup latitud Mekah, iaitu $\left(90^{\circ}-\varphi m\right)$. Arah kiblat tersebut boleh menghala ke arah timur dan barat bergantung kepada nilai kedudukan longitud tempatan.

\section{Rumus untuk kawasan latitud $0^{\circ}$}

$$
90^{\circ}-\varphi \mathrm{m}=\operatorname{arah} \text { kiblat }(\text { Timur/Barat })
$$

\section{Jadual 3: Contoh Hitungan Kategori Latitud $0^{\circ}$}

\begin{tabular}{|c|c|}
\hline \multicolumn{2}{|c|}{ Contoh hitungan Kategori latitud $0^{\circ}$} \\
\hline $\begin{array}{l}\text { Pulau Ruib (Papua) } 68^{\circ} 39^{\prime} \text { barat } \\
\left(\lambda t=130.4^{\circ}\right)\end{array}$ & $\begin{array}{l}\text { Arah kiblat adalah sebanyak } \\
\text { nilai pencukup latitud Mekah } \\
\text { iaitu ke barat bagi Pulau }\end{array}$ \\
\hline $\begin{array}{l}\text { Migzania (Brazil) } 68^{\circ} 39^{\prime} \text { timur } \\
\left(\lambda \mathrm{t}=-49.40^{\circ}\right) .\end{array}$ & $\begin{array}{l}\text { Ruib dan ke timur bagi Pulau } \\
\text { Migzania }\end{array}$ \\
\hline
\end{tabular}

Untuk kategori kedua, kawasan yang dihitung arah kiblatnya mempunyai nilai latitud lebih daripada $0^{\circ}$. Rumus ini tidak boleh digunakan bagi kawasan berlatitud $0^{\circ}$ dalam hitungan arah kiblat. Berikut adalah rumus untuk hitungan arah kiblat bagi kawasan latitud $>0^{\circ}$.

\section{Rumus untuk kawasan latitud $>0^{\circ}$}

$\log \sin \varphi m+\log \sin \varphi t=x$

$\log \sin \left(90^{\circ}-\mathrm{x}\right)-\log \sin \left(90^{\circ}-\varphi \mathrm{m}\right)=\mathrm{Q}$ (cenderung arah kiblat)

Maka Q ialah sudut arah kiblat

32 Sheikh Tahir, Pati Kiraan, 23. 
Kes 4: Beza antara $K$ Mekah dan $\kappa$ kawasan yang dikira $>90^{\circ}$ namun $<180^{\circ}$

Berikut ialah contoh-contoh kawasan yang memenuhi ciri-ciri kes 4 iaitu beza longitud antara Mekah dan kawasan sebanyak lebih $90^{\circ}$ namun kurang daripada $180^{\circ}$.

\section{Jadual 3: Contoh kawasan yang memiliki beza antara longitud Mekah dan longitud kawasan yang $>90^{\circ}$ namun $<$ $180^{\circ}$}

\begin{tabular}{ll}
\hline Nama Kawasan & Koordinat Kawasan \\
\hline Yokohama & $35^{\circ} 26^{\prime} 37.35^{\prime \prime} \mathrm{U} ; 139^{\circ} 38^{\prime} 16.8^{\prime \prime} \mathrm{T}$ \\
Mexico & $23^{\circ} 38^{\prime} 4.2^{\prime} \mathrm{U} ; 102^{\circ} 33^{\prime} 10^{\prime \prime} \mathrm{B}$ \\
San Salvador & $13^{\circ} 41^{\prime} 34.58^{\prime \prime} \mathrm{U} ; 89^{\circ} 13^{\prime} 5.49^{\prime \prime} \mathrm{B}$ \\
San Francisco & $37^{\circ} 46^{\prime} 29.74^{\prime} \mathrm{U} ; 122^{\circ} 25^{\prime} 9.9^{\prime \prime} \mathrm{B}$ \\
New York & $40^{\circ} 42^{\prime} 45.99^{\prime \prime} \mathrm{U} ; 4^{\circ} 0^{\prime} 21.5^{\prime \prime} \mathrm{B}$ \\
\hline
\end{tabular}

Sumber: Google Maps

Pengiraan arah kiblat untuk kes ke empat adalah berdasarkan rumus berikut:

\section{Rumus untuk kes 4:}

$$
\begin{aligned}
& 180^{\circ}-\Delta \lambda=\mathrm{x} \\
& \log \sin \mathrm{x}+\log \sin \left(90^{\circ}-\varphi \mathrm{m}\right)=\mathrm{A} \\
& \log \sin \left(90^{\circ}-\mathrm{A}\right)-\log \sin \varphi \mathrm{m}=\mathrm{B} \\
& \mathrm{C}=\mathrm{B}-\left(90^{\circ}-\varphi \mathrm{t}\right)\left(\mathrm{jika} \text { tidak lebih } 90^{\circ}\right) \\
& =180^{\circ}-\mathrm{B}\left(\mathrm{jika} \operatorname{lebih} 90^{\circ}\right) \\
& \text { Log } \sin \left(90^{\circ}-\mathrm{A}\right)+\log \sin \mathrm{C}=\alpha \text { (nilai azimut Mekah) } \\
& \text { Log sin } \mathrm{A}-\log \sin \left(90^{\circ}-\alpha\right)=\mathrm{Q} \text { (cenderung arah kiblat) } \\
& \text { Maka Q ialah sudut arah kiblat }
\end{aligned}
$$

Kiraan kiblat untuk bahagian ini sama seperti bahagian yang kedua tadi, namun begitu terlebih dahulu perlu ditolak $180^{\circ}$ kepada nilai beza longitud antara kawasan dengan Mekah.

\section{Kes 5: Beza antara $\Lambda$ Mekah dan $\Lambda$ kawasan yang dikira $=180^{\circ}$}

Bahagian yang terakhir ialah bahagian yang kelima iaitu bagi kawasan yang beza longitud antara Mekah dan kawasan adalah 
sebanyak $180^{\circ}$. Untuk kawasan ini, arah kiblat akan berada di arah utara jika nilai latitud tempatan, $(\varphi t)$ kurang daripada latitud Mekah, ( $\varphi m)$. Arah kiblat akan berada di arah selatan pula jika nilai latitud kawasan lebih daripada nilai latitud Mekah. Arah kiblat akan berada di semua arah jika latitud kawasan tersebut berada di sebelah selatan dan nilai latitud kawasan sama dengan nilai latitud Mekah. Ia dinamakan sebagai titik antipodal. ${ }^{33}$ Namun begitu, kawasan tersebut tidak didiami oleh manusia iaitu di Lautan Atlantik Selatan. Akhir sekali, arah kiblat boleh saja berada di arah timur atau barat bergantung kepada kedudukan longitud kawasan sama ada ia lebih dari longitud Mekah atau kurang.

Kesimpulannya, kaedah pertama ini adalah kaedah yang digelar Sheikh Tahir sebagai kaedah Rị̣wān Afandī. Ini kerana, sumber rujukannya adalah melalui zìj yang ditulis oleh tokoh berikut. Kaedah ini menggunakan logaritma sinus (juyz̄ b) dalam pengiraan. Ia dijelaskan dengan terperinci dengan membahagikannya kepada lima bahagian berdasarkan beza longitud antara Mekah dan tempatan.

\section{Kaedah Kedua: Kaedah Abī al-Faḍl}

Berdasarkan analisis yang telah dilakukan oleh pengkaji, kaedah yang kedua ini agak ringkas berbanding kaedah yang sebelum ini. Kaedah ini diperolehi Sheikh Tahir ketika mana beliau melanjutkan pelajarannya di Mesir melalui gurunya yang mulia iaitu Sheikh Muhammad Abī al-Faḍl. Pengakuan mengenai sumber rujukan kaedah kedua ditulis oleh Sheikh Tahir di dalam kitabnya sebagaimana yang berikut:

"Kaedah ini telah hamba terima daripada yang mulia al-Sayyid Muhamad Abī al-Faḍl, barang yang dibalaskan Allah kerana jasanya kepada hamba." 34

Oleh kerana sumber rujukan kaedah ini adalah daripada Sheikh Muhammad Abī al-Faḍl maka kaedah kedua ini dinamakan sebagai kaedah Abī al-Faḍl. Kaedah ini semasa diterima olehnya

33 Kedudukan setentang dengan Bumi, laman sesawang English Oxford Living Dictionaries, dicapai 1 Oktober 2018, https:// en.oxforddictionaries.com/definition/antipodal.

34 Sheikh Tahir, Pati Kiraan, 25. 
hanyalah merupakan kiraan di kawasan-kawasan yang memiliki beza longitud dengan Mekah kurang dari $90^{\circ}$ serta kawasan yang berada disebelah utara sahaja. ${ }^{35}$ Namun, Sheikh Tahir telah melakukan usaha penambahbaikan terhadap kaedah ini. Kaedah ini telah ditambah baik sehingga kawasan yang berada di selatan dan yang memiliki beza longitud antara Mekah dan tempatan sebanyak $90^{\circ}$ atau lebih dapat juga dikira. Kaedah ini sama juga teknik penyampaiannya sebagaimana kaedah yang pertama iaitu dalam bentuk penceritaan sebagaimana yang boleh dilihat dalam contoh petikan dalam kitab Pati Kiraan seperti berikut:

“...adalah kaedah ini tatkala diterima tertentu kiraannya bagi negeri-negeri yang disebelah utara sahaja yaitu negeri-negeri yang ada antaranya dengan Mekah kurang daripada (90) degree, maka kemudian daripada menjalankan beberapa perusahaan yang mengambil masa yang panjang dan bahas yang berturut-turut dan pencubaan yang berbagai-bagai dapatlah hamba taufik memindanya dengan sempurna hingga jadilah ia kaedah yang melengkapi negeri-negeri yang disebelah utara dan selatan yang ada jarak antaranya dengan Mekah kurang daripada (90) degree atau lebih... " 36

Kaedah kedua ini lebih ringkas berbanding kaedah sebelum ini kerana tidak membincangkan tentang pembahagian kawasan berdasarkan jarak longitud antara dua kawasan (Mekah dan tempatan). Arah kiblat boleh dicari menggunakan kaedah ini tidak kira sama ada ia kurang dari $90^{\circ}$ atau lebih. Jika diteliti, kaedah pengiraan di atas menggunakan kaedah rumus tangen (zil). Selain itu, dalam kaedah kiraan ini, Sheikh Tahir masih lagi menggunakan istilah 'simpanan' bagi hasil tambah atau hasil tolak dalam proses pengiraannya. Untuk memudahkan kefahaman pembaca, pengkaji telah menggantikan istilah 'simpanan' kepada istilah 'langkah' sepertimana kaedah pertama.

\section{Rumus untuk kaedah kedua: Kaedah $A b \bar{\imath}$ al-Faḍl}

$$
\begin{aligned}
& \log \tan \varphi m-\log \sin \left(90^{\circ}-\Delta \lambda\right)=A \\
& A-\varphi t=x
\end{aligned}
$$

35 Sheikh Tahir, Pati Kiraan, 25.

36 Sheikh Tahir, Pati Kiraan, 25. 


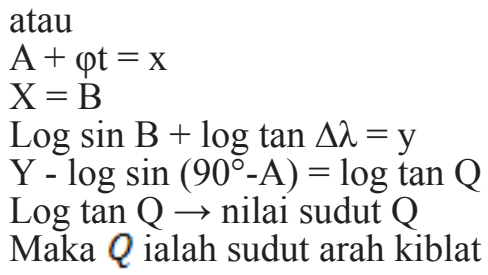

Kesimpulannya, kaedah kiraan kedua ini adalah kaedah yang digelar Sheikh Tahir sebagai kaedah Abī al-Faḍl. Kaedah ini diperolehinya melalui Sheikh Muhammad Abī al-Faḍl ketika beliau melanjutkan pelajaran di al-Azhar, Mesir pada tahun $1310 \mathrm{H}$ bersamaan $1894 \mathrm{M} \cdot{ }^{37}$ Kaedah ini menggunakan logaritma tangen (zīl) dalam pengiraan. Kaedah ini lebih ringkas dan pendek berbanding kaedah pertama kerana tidak menghuraikan perbezaan longitud antara Mekah dan longitud kawasan secara terperinci.

\section{Kaedah Ketiga: Kaedah Pelayaran/al-Bahríyyah}

Kaedah yang terakhir ini ialah kaedah yang diperolehi daripada buku-buku pelayaran. Kaedah ini digunakan oleh kapten-kapten kapal yang berlayar di lautan. Kaedah ini penting dan digunakan oleh para kapten untuk memudahkan mereka untuk mengetahui destinasi yang mahu dituju. Sheikh Tahir telah mendapatkan bantuan dari Pendeta Za'ba untuk menterjemahkan kaedah ini. Za'ba pada ketika itu merupakan seorang guru matapelajaran geografi di Penang Free School, Pulau Pinang. Berikut adalah petikan yang diambil dari kitab Pati Kiraan yang menyatakan tentang kaedah ketiga ini:

“...Iaitu satu daripada kaedah yang digunakan oleh kapten-kapten kapal yang mengarung lautan besar-besar, sanya dengan jalan ini mereka dapat mengenal pantai-pantai yang akan ditujunya atau beting-beting yang akan disiahkannya di tengahtengah laut itu, kaedah ini diterjemahkan daripada buku-buku mereka itu oleh guru yang bijaksana Encik Zainal Abidin yang mengajar ilmu geografi di

37 Mustajab, Sarim, "Syeikh Muhammad Tahir Jalaluddin al-Falaki, Pelopor Gerakan Islah Islamiyyah di Tanah Melayu," 2. Bandingkan dengan Mafri Amir di dalam tesis beliau, Reformasi Islam, 74. 
sekolah Inggeris (Free School), Pulau Pinang,..." ${ }^{38}$

Kaedah ini telah dilakukan beberapa pindaan sehinggalah berhasil untuk digunakan dan ia tidak memiliki banyak perbezaan dengan dua kaedah yang terawal melainkan hanya perbezaan beberapa minit sahaja yang tidak ketara. Perkara ini menunjukkan konsistensi ketepatan kaedah Sheikh Tahir. Jika dilihat, kaedah ini agak panjang dan berbeza dengan dua kaedah yang sebelum ini. Berdasarkan kajian oleh Baharrudin Zainal, beliau telah menyesuaikan kaedah ini sebagai kaedah yang menggunakan penyelesaian serentak rumus tangen (zil).

Kaedah ini mirip dengan analogi Napier. ${ }^{39}$ Analogi tersebut dapat membantu ingatan tentang trigonometri sfera dengan berasaskan alat yang dipanggil rod Napier. Rod Napier merupakan kayu yang diukir dengan sifir pendaraban yang mudah digunakan untuk pendaraban kekisi. Menurut Baharrudin Zainal juga, rumus tersebut diambil daripada rumus yang dibuat oleh Abu Wafa al-Buzjani (940M) dan telah dikembangkan. ${ }^{40}$ Berikut ialah penyesuaian rumus Sheikh Tahir dengan analogi Napier.

\section{Rumus berdasarkan analogi Napier:}

$$
\begin{aligned}
\operatorname{Tan} 1 / 2(A+B) & =(\operatorname{kos} 1 / 2(a-b) / \operatorname{kos} 1 / 2(a+b)) \\
\text { dan } & \text { kotangen } 1 / 2 C \\
\operatorname{Tan} 1 / 2(A-B) & =(\operatorname{kos} 1 / 2(a-b) / \operatorname{kos} 1 / 2(a+b)) \text { kotangen } 1 / 2 C
\end{aligned}
$$

Kemudian, pengkaji telah mengeluarkan singkatan rumus kaedah kiraan ketiga. Berikut adalah ringkasan rumus tersebut:

38 Sheikh Tahir, Pati Kiraan, 26-27.

39 Nama beliau ialah John Napier dan lahir pada tahun 1550 di Istana Merchiston, Edinburgh. John Adalah anak sulung daripada 13 orang adik beradik. Beliau meninggal dunia pada tahun 1617. Karya beliau tentang logh adalah Descreptio (1614) dan Constructio (1619). P.Dedron Jltard, Mathematisc and Mathematicians 1, 228-229.

40 Dilahirkan di Buzshan di Khurasan, Iran. Penemuan beliau adalah berkaitan dengan kaedah pengiraan menggunakan jadual sinus. Beliau juga telah menggunakan tangen dan juga mengira jadual tangen. Florian Cajori, A History of Mathematics, 5th ed. (USA: AMS Chelsea Publishing, 1893), 105-106. 


\section{Rumus kaedah ketiga: Kaedah Pelayaran/al- Bahríyyah}

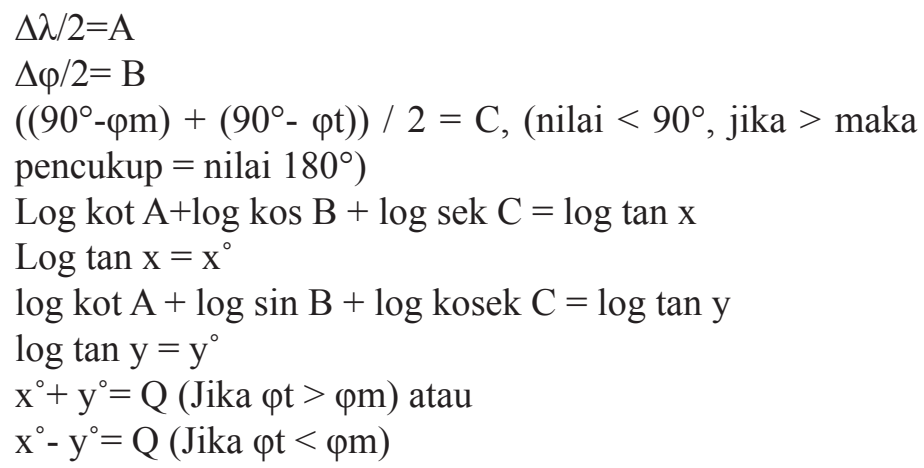

Kaedah yang ketiga ini juga menggunakan istilah 'simpanan'. Pengkaji juga telah menggunakan istilah 'langkah' sebagai ganti istilah tersebut. Selain itu, terdapat juga istilah unik yang digunakan di dalam kaedah ini iaitu 'jawab'. Pengkaji telah menukar istilah tersebut kepada simbol $\mathrm{x}$ dan y yang mana ' $\mathrm{x}$ ' adalah simbol ganti kepada istilah 'jawab yang pertama' dan ' $y$ ' adalah simbol ganti kepada istilah 'jawab yang kedua'. Penggunaan istilah cenderung kiblat dan hala kiblat pasti akan mengelirukan pembaca. Terdapat perbezaan maksud antara dua istilah tersebut sepertimana yang telah dijelaskan oleh Sheikh Tahir di dalam kitab Pati Kiraan seperti berikut:

"Samt al-qiblah itu ialah sepotong daripada dā'irah (lingkungan) ufuk negeri yang hendak dicari samt al-qiblah padanya antara tempat pertemuan ufuk dengan dā'irah mu'addal al-nahār, dan tempat pertemuan ufuk lagi dengan dā'irah irtifä' yang melalui kutub ufuk negeri Mekah dan kutub ufuk negeri yang dikehendakkan samt al-qiblah padanya, atau kita kata samt al-qiblah itu ialah beberapa darjah pada ufuk negeri itu dari titik i'tidāl kepihak 
kutub." ${ }^{41}$

"Adapun cenderung kiblat itu maka ialah sepotong daripada dā'irah ufuk negeri itu antara titik utara atau selatan dan pertemuan ufuk negeri yang memotong dā'irah irtifā' yang melalui dua kutub negeri yang tersebut, atau kita kata: cenderung kiblat itu ialah beberapa darjah pada ufuk negeri itu dari kutub kepihak titik i'tidāl. Maka pencukupnya itu ialah samt al-qiblah." ${ }_{42}$

Berdasarkan keterangan di atas, hala kiblat (samt al-qiblah) ialah nilai arah kiblat yang diukur daripada ufuk ke kutub manakala cenderung kiblat ialah nilai arah kiblat yang diukur daripada kutub ke ufuk. Namun begitu, Ustaz Hanafiah Abdul Razak $^{43}$ telah menjelaskan bahawa perbezaan istilah hala kiblat (samt al-qiblah) dan cenderung kiblat (inhiräf al-qiblah) adalah berdasarkan kepada pentakrifan ulama falak dan ulama fekah. Istilah samt ${ }^{44}$ adalah asal kepada perkataan 'azimut' yang menunjukkan nilai darjah arah kiblat dalam bulatan sfera yang digunakan oleh ulama falak. Manakala istilah cenderung $(\text { inhirâf })^{45}$

41 Sheikh Tahir merupakan seorang yang begitu mementingkan dalil dalam setiap perkara ibadah yang dilakukannya termasuklah dalam urusan menentukan arah kiblat. Seseorang tidak boleh berijtihad untuk menghadap kearah kiblat kecuali setelah mengetahui dalildalil untuk menentukan arah kiblat. Antara dalil-dalil kiblat yang dinyatakan oleh beliau adalah menggunakan bintang, matahari, bulan, angin (paling lemah) dan kutub (paling kuat). Tidak boleh berijtihad sudah menghadap kearah kiblat dengan sangkaan sematamata. Syeikh Tahir, Jawapan Syeikh Tahir Terhadap Tulisan Tok Janggut Mengenai Kiblat, No Penerimaan: 2006/0035894, (Kuala Lumpur: Arkib Negara Malaysia, t.t.).

42 Sheikh Tahir, Pati Kiraan, 21-22.

43 Panel Pakar Falak, Jabatan Kemajuan Islam Malaysia (JAKIM).

44 Azimut, laman sesawang Kamus al-Maany, dicapai 5 September 2018, https://www.almaany.com/en/dict/aren $/ \%$ D $8 \%$ B3 $\%$ D $\% 85 \%$ D $8 \%$ AA/

45 Pesongan/Deflection, laman sesawang Kamus al-Maany, dicapai 3 Oktober 2018, https://www.almaany.com/en/dict/ar-en/\%D8\%A5\% D9\%86\%D8\%AD\%D8\%B1\%D8\%A7\%D9\%81/. 
adalah istilah umum yang digunakan oleh ulama fekah dalam menyatakan hala kiblat. ${ }^{46}$

Pengkaji telah menemukan rajah falak (rajah 2 di bawah) yang berkaitan dengan formula kaedah yang ketiga ini. Rajah 2 tersebut merupakan kiraan arah kiblat di Port Weld (Kuala Sepetang), Perak. Berdasarkan catatan pada rajah, ia adalah merupakan rajah yang diperolehi Sheikh Tahir daripada Zainal Abidin Ahmad. ${ }^{47}$

Rumus bagi rajah 2 di bawah:

$$
\begin{aligned}
& \operatorname{Tan} 1 / 2(A+B)=\operatorname{Kos} 1 / 2(a-b) \operatorname{Sek} 1 / 2(a+b) \operatorname{Kot} C / 2 \\
& \operatorname{Tan} 1 / 2(A-B)=\operatorname{Sin} 1 / 2(a-b) \operatorname{Kosek}^{1} 1 / 2(a+b) \operatorname{Kot} C / 2
\end{aligned}
$$

Rajah 2: Rajah Sudut Arah Kiblat di Port Weld berdasarkan

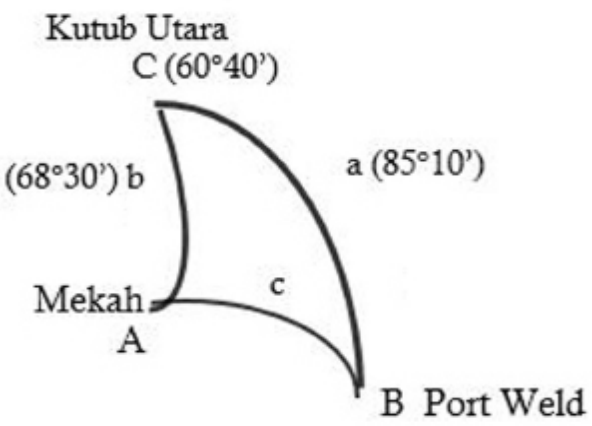

Sumber: Arkib Negara Malaysia

Rumus berikut hampir sama dengan analogi Napier yang telah disebut sebelum ini. Berikut ialah contoh hitungan arah kiblat di Port Weld dari Mekah dengan berdasarkan kepada rajah 2 di atas:

$$
\begin{aligned}
& (a+b)=85^{\circ} 10^{\prime}+68^{\circ} 30^{\prime} \\
& =153^{\circ} 40^{\prime} \\
& (a+b) / 2=76^{\circ} 50^{\prime}
\end{aligned}
$$

46 Berdasarkan soal jawab pengkaji kepada Ustaz Hanafiah Abdul Razak dalam slot rakaman bagi rancangan al-Ustaz (Kosmos: Ilmu dari bintang) siaran Astro Oasis pada 11 dan 12 Ogos 2018 bertempat di Akademi Pengajian Islam, Universiti Malaya.

47 SP 10/1444, Rajah Umum Falak dari Zainal Abidin BA, Pulau Pinang 1/10/1950 (Versi Inggeris), 2006/0037032. 


$$
\begin{aligned}
& (a-b)=85^{\circ} 10^{\prime}-68^{\circ} 30^{\prime} \\
& =16^{\circ} 40^{\prime} \\
& (a-b) / 2=8^{\circ} 20^{\prime} \\
& \left(\text { Cosine } 8^{\circ} 20^{\prime}+\operatorname{Sec} 76^{\circ} 50^{\prime}+\operatorname{Cot} 30^{\circ} 20^{\prime}\right) \\
& =1.9954+0.6425+0.8706 \\
& =0.8706 \\
& =82^{\circ} 19^{\prime} \\
& \left(\text { Cot } 30^{\circ} 20^{\prime}+\operatorname{Sine} 8^{\circ} 20^{\prime}+\operatorname{Cosec} 76^{\circ} 50^{\prime}\right) \\
& =0.2327+9.1611+0.0115 \\
& =9.4053 \\
& =14^{\circ} 16^{\prime} \\
& 82^{\circ} 19^{\prime}-14^{\circ} 16^{\prime}=68^{\circ} 03^{\prime} \\
& 90^{\circ}-68^{\circ} 03^{\prime}=21^{\circ} 57^{\prime}(\text { Barat Utara })
\end{aligned}
$$

\section{ANALISIS DAN PERBINCANGAN}

\section{Perbezaan Data Hitungan dan Analisis}

Jadual 4: Beza Kiraan antara Kaedah-Kaedah Sheikh Tahir dengan Kaedah Moden

\begin{tabular}{|c|l|c|c|c|}
\hline Bil. & $\begin{array}{l}\text { Nama Tempat/ } \\
\text { Beza Kiraan }\end{array}$ & $\begin{array}{l}\text { Ridwān Afandī } \\
(\% / \text { darjah) }\end{array}$ & $\begin{array}{l}\text { Abī al-Fạ̣l } \\
(\% / \text { darjah })\end{array}$ & $\begin{array}{l}\text { al-Bahrīyyah } \\
(\% / \text { darjah) }\end{array}$ \\
\hline 1. & Jakarta & 04.26 & 04.26 & 04.25 \\
\hline 2. & Bukit Tinggi & 00.17 & 00.17 & 00.00 \\
\hline 3. & Pulau Pinang & 00.02 & 00.06 & 00.00 \\
\hline 4. & Singapura & 00.01 & 00.01 & 00.01 \\
\hline 5. & Padang & 00.54 & 00.54 & 00.53 \\
\hline 6. & Tanah Merah & 01.00 & 01.54 & 00.01 \\
\hline
\end{tabular}

Jadual di atas menunjukkan beza data kiraan antara tiga kaedah Sheikh Tahir iaitu kaedah pertama, kedua dan ketiga. Enam kawasan telah dipilih untuk melihat perbezaan data kiraan arah kiblat berdasarkan tiga kaedah Sheikh Tahir. Nilai kiraan yang diambil adalah nilai beza arah kiblat setiap kaedah Sheikh Tahir 
yang ditolakkan dengan nilai arah kiblat menggunakan kaedah moden..$^{48}$

Data ini bertujuan untuk menganalisis perbezaan antara ketigaketiga kaedah Sheikh Tahir. Data kiraan di atas telah menjelaskan bahawa terdapat beza jawapan antara ketiga-tiga kaedah. Terdapat data yang menunjukkan persamaan hasil jawapan yang membuktikan tidak wujudnya beza nilai jawapan antara ketigatiga kaedah. Kawasan tersebut adalah seperti yang dilihat di Jadual 4 di atas di kawasan Singapura yang masing-masing mempunyai beza kiraan dengan kaedah moden sebanyak 00.01 darjah. Namun begitu, kebanyakan hasil jawapan menunjukkan wujudnya perbezaan jawapan antara ketiga-tiga kaedah. Perbezaan tersebut sehingga hampir mencapai dua darjah seperti yang dilihat pada kawasan Tanah Merah yang mana kaedah kedua menunjukkan beza kiraan yang ketara iaitu sebanyak 1.54 berbanding kaedah pertama dan ketiga yang mana masing-masing adalah 01.00 darjah dan 00.01 darjah.

Berdasarkan hasil kiraan yang diperolehi, pengkaji dapat melihat terdapat perbezaan yang besar di kawasan Jakarta iaitu sehingga melebihi empat darjah. Namun begitu, hasil jawapan antara ketiga-tiga kaedah tetap menunjukkan corak bacaan yang lebih kurang sama. Oleh yang demikian, ini menunjukkan bahawa apabila perbezaan bacaan adalah lebih kurang sama, maka kejituan juga adalah sama walaupun menggunakan data yang berbeza. Dengan itu, pengkaji dapat menyimpulkan bahawa kaedah beliau adalah tepat. Bukti ketepatan berikut boleh dilihat dengan nilai beza bacaan 0 darjah pada data jadual 1 bagi kawasan Bukit Tinggi dan Pulau Pinang. Selain itu, pengkaji juga dapat membenarkan kenyataan Sheikh Tahir bahawa beza kiraan antara ketiga-tiga kaedah hanyalah beberapa minit yang tidak menjejaskan sebagaimana yang berikut:

"...dan didapati pendapatan kiraannya bersetujuanlah dengan pendapatan dua kaedah yang telah lalu, walhāssil tiada perbezaan antara pendapatan ketiga-tiga kaedah itu melainkan sedikit minit yang tiada boleh menjadikan apa-apa..."

(Sheikh Tahir, 1938)

48 Unit Falak, Bahagian Penyelidikan, Jabatan Kemajuan Islam Malaysia, Kaedah Panduan Falak Syarie, 14-15. 
Sebagai kesimpulan, kesemua kaedah penentuan arah kiblat yang telah dipaparkan oleh Sheikh Tahir dalam kitabnya membuktikan kemampuan Sheikh Tahir yang luar biasa dalam memahami perbezaan kaedah kiraan. Berdasarkan penjelasannya terhadap setiap kaedah tersebut, beliau memang mempunyai kemampuan yang baik dalam memahami trigonometri sfera. Ketiga-tiga kaedah beliau boleh dikira sebagai menghampiri ketepatan berikutan terdapat kiraan yang benar-benar tepat walaupun terdapat juga perbezaan yang menghampiri kepada lima darjah. Diantara ketiga-tiga kaedah berikut, kaedah ketiga adalah kaedah yang paling rendah beza kiraan.

\section{PERBINCANGAN}

Berdasarkan hasil kiraan yang diperolehi, pengkaji dapat menyatakan bahawa kaedah Sheikh Tahir adalah tepat kerana hampir dengan bacaan kiraan moden. Kaedah tersebut tepat berdasarkan hasil beza kiraan yang terdapat dalam Jadual 1 di atas. Kaedah dalam Pati Kiraan tepat kerana pengiraan menggunakan jadual log manakala kiraan moden menggunakan kiraan berdasarkan kalkulator. Kiraan menggunakan log hanya memasukkan nilai-nilai yang terdapat dalam jadual. Oleh yang demikian tidak terdapat beza yang ketara hasil kiraannya. Apa yang membezakannya adalah formula matematik yang digunakan kerana berdasarkan log. Selain itu, walaupun terdapat beza hasil kiraan yang mencapai sehingga lima darjah seperti yang berlaku pada kawasan Jakarta pada Jadual 2 di atas, hasil beza tersebut tetap konsisten antara satu sama lain. Oleh yang demikian, ini menunjukkan bahawa apabila perbezaan bacaan adalah hampir sama, maka kejituan juga adalah tinggi dan ini menunjukkan kaedah tersebut boleh dikatakan sebagai tepat. Kemungkinan yang boleh dinyatakan disini adalah kerana nilai koordinat yang diambil adalah berbeza dan persoalan tersebut barangkali boleh dijawab oleh pengkaji akan datang. Dengan itu, pengkaji dapat menyimpulkan sekali lagi bahawa kaedah beliau adalah tepat dan boleh dirujuk sebagai kaedah penentuan arah kiblat. Selain itu, pengkaji juga dapat membenarkan kenyataan Sheikh Tahir bahawa beza kiraan antara ketiga-tiga kaedah hanyalah beberapa minit yang tidak menjejaskan hasil hitungan arah kiblat. 


\section{KESIMPULAN}

Pengkaji boleh membuat kesimpulan bahawa penentuan arah kiblat dalam kitab ini agak mudah dari sudut aplikasi penggunaan kaedah logaritma. Namun begitu, ia agak sukar dalam memahami formula yang digunakan. Pengkaji hanya boleh melakukan penyesuaian terhadap kaedah matematik yang digunakan namun pembuktian kaedah tersebut masih belum lagi berjaya. Pengkaji telah berjaya menghuraikan keseluruhan kaedah penentuan arah kiblat dengan penggunaan bahasa yang lebih moden dan ringkas serta dekat dengan penerimaan masyarakat hari ini. Berdasarkan perbandingan kiraan yang dilakukan terhadap kaedah Sheikh Tahir dengan kaedah moden menunjukkan bahawa kaedah Sheikh Tahir boleh dikira menghampiri kepada ketepatan. Namun begitu, ketepatan tersebut agak tidak konsisten serta menghasilkan beza kiraan yang agak ketara. Secara keseluruhannya kaedah penentuan arah kiblat Sheikh Tahir boleh dikira sebagai kaedah yang agak tepat yang membuktikan bahawa Sheikh Tahir adalah tokoh yang berjaya membawa kaedah baru yang agak mudah dan moden berdasarkan penggunaan jadual logaritma yang menggunakan operasi tambah dan tolak sahaja.

\section{RUJUKAN}

Abū 'Abd Allāh Muhammad bin Idris al-Shāfi'ī. "al-Umm”, laman sesawang al-Maktabah al-Shāmilah, http://shamela.ws/ browse.php/book-1655\#page-99, dicapai pada 16 Januari 2018.

Amir, Mafri. Reformasi Islam Dunia Melayu-Indonesia (Studi Pemikiran, Gerakan dan Pengaruh Syeikh Muhammad Tahir Jalal al-Din 1869-1956. Jakarta: Universitas Islam Jakarta, 2008.

Azhari, Susiknan. "Perkembangan Kajian Astronomi Islam di Alam Melayu," Jurnal Fiqh (2010), 167-184.

Azra, Azyumardi. "The Transmission of al-Manar's Reformism to The Malay-Indonesia World: The Cases of al-Imam and alMunir." Studia Islamika vol. 6, no. 3 (1999), 75-100.

Cajori, Florian. A Histroy of Mathematics. USA: AMS Chelsea Publishing, 1893. 
Djamily, Bachtiar. Riwayat Hidup dan Perjuangan Syekh Tahir Jalaluddin al-Falaqi al-Azhari. Kuala Lumpur: Asmah Publisher, 1994.

English Oxford Living Dictionaries. n.d. https:// en.oxforddictionaries.com, dicapai pada 1 Oktober 2018.

Faisal@Ahmad Faisal Abdul Hamid \& Mohd Puaad Abdul Malik. "Analisis Penulisan Syekh Muhammad Tahir Jalaluddin dalam Kitab Ta'yid Tadkhirah Muttabi“ al-Sunnah.” Jurnal al-Tamaddun, vol. 12, no. 1 (2017), 67-78.

Ilyas, Mohammad. Astronomi Islam dan Perkembangan Sains: Kegemilangan Masa Lalu Cabaran Masa Depan. Kuala Lumpur: Institut Terjemahan Negara Malaysia Berhad, 2003.

Ilyas, Muhammad. Astronomy of Islamic Calendar. Kuala Lumpur: A.S. NORDEEN, 1997.

Jalaluddin, Sheikh Tahir. Jadawil Nukhbat al-Taqrirah. Singapore: Sin Sheng Press, 1954.

Jalaluddin, Sheikh Tahir. Pati Kiraan Pada Menentukan Waktu Yang Lima dan Hala Kiblat dengan Logaritma. Singapura: Royal Press, 1937.

Jltard, P.Dedron. Mathematics and Mathematicians I. Milton Keynes: Open University Press, 1978.

Laila Mahya. "Studi Komparasi Tentang Keakurasian Hisab Arah Kiblat Menurut Syekh Muhammad Thahir Jalaluddin alMinangkabawi dalam Kitab Pati Kiraan Pada Menentukan Waktu Yang Lima dan Hala Kiblat dengan Logaritma dan K.H Zubair Umar al-Jailani dalam Kitab al-Khulasah alWafiyyah." Latihan Ilmiah, Sarjana Muda, IAIN Walisongo, Semarang, 2011.

Laman sesawang Kamus al-Maany, https://www.almaany.com/ en/dict/ar-en/\%D8\%B3\%D9\%85\%D8\%AA/, 5 September 2018 .

Manuskrip No Penerimaan (2006/0037032), (SP 10/1444), Rajah Umum Falak dari Zainal Abidin BA, Pulau Pinang 1/10/1950 (Versi Inggeris). 
Manuskrip No Penerimaan: (2006/0035894), Jawapan Syeikh Tahir Terhadap Tulisan Tok Janggut Mengenai Kiblat, Arkib Negara Malaysia Kuala Lumpur.

Manuskrip No. Penerimaan: (2006/0046405), Ringkasan Riwayat Hidup Zaaba, Arkib Negara Malaysia; Kuala Lumpur.

Manuskrip SP 10 622/36, No. Penerimaan: (2006/0036258), Surat dari Za'ba Kepada Sheikh Tahir Mengenai Terjemahan Kitab Sheikh Tahir, 27 September 1937.

Mohamad Amin Abu Bakar, Mohd. Ridzuan Awang dan Ibnor Azli Ibrahim. "Sumbangan Syeikh Tahir Jalaluddin (1860-1965) Terhadap Perkembangan Fiqh di Nusantara." Prosiding Nadwah Ulama Nusantara (NUN) IV: Ulama Pemacu Transformasi Negara, Universiti Kebangsaan Malaysia, 2011.

Mustajab, Sarim. "Sheikh Tahir Jalaluddin al-Falaki." Kertas Kerja, Seminar Keilmuan Falak Sheikh Tahir Jalaluddin dan Sheikh Abdullah Fahim: Perintis Ilmu Falak Moden, Pulau Pinang, 2005.

Mustajab, Sarim. "Syeikh Muhammad Tahir Jalaluddin al-Falaki, Pelopor Gerakan Islah Islamiyyah di Tanah Melayu." Malaysian in History, vol. 20, no. 23 (1977), 1-11.

Noorzahidah Mohd Zain, Faisal@ Ahmad Faisal Abdul Hamid. "Sheikh Tahir Jalaluddin dan Karya Bertulisan Jawi Beliau di Arkib Negara Malaysia." Jurnal al-Muqaddimah (2014), 29-38.

Pusat Rujukan dan Persuratan Melayu. n.d. November 2018, http://prpm.dbp.gov.my, dicapai pada 2 November 2018.

Saadan Man, Mohd Zambri Zainuddin, Mohd Roslan Mohd Nor, Mohd Anuar Ramli, Rahimin Affandi Abdul Rahim, Rushdi Ramli \& Ridzwan Ahmad. "The Development of Islamic Astronomy Studies in Higher Learning Institution in Malaysia." Middle-East Journal of Scientific Research, vol. 12, no. 1 (2012), 108-113.

Salleh, Kamaruddin. "Transformasi Pemikiran Pembaharuan dan Modenisme di Malaysia: Satu Penelitian Awal." International Journal of Islamic Thought (2012), 23-37. 
Siti Muslifah. "Analisis Pemikiran Syeikh Muhammad Tahir Jalaluddin al-Minangkabawi Tentang Penentuan Waktu Salat dalam Kitab Pati Kiraan dan Akurasinya." Disertasi Sarjana, Institut Agama Islam Negeri (IAIN) Walisongo, 2013.

Unit Falak, Bahagian Penyelidikan, Jabatan Kemajuan Islam Malaysia. Kaedah Panduan Falak Syarie. Kuala Lumpur: JAKIM, 2001.

Zainal, Baharrudin. "Grafiti Falak Rumpun Melayu Melalui Kajian Teks Utama." Menemui Matematik vol. 32 (2010), 57.

Zainal, Baharrudin. "Ulasan Karya Falak Sheikh Tahir Jalaluddin." Seminar Keilmuan Falak "Sheikh Tahir Jalaluddin dan Sheikh Abdullah Fahim': Perintis Ilmu Falak Moden, Pulau Pinang, 2005.

Zainal, Baharrudin. Pentahkikan Naskhah Falak Alam Melayu. Selangor: Jabatan Mufti Negeri Selangor, 2016.

Zakariya, Hafiz. "An Overview of Syeikh Tahir Jalaluddin's Major Writings and Contributions." Seminar Kebangkitan Gerakan Islah di Alam Melayu, Institut Kefahaman Islam Malaysia, Kuala Lumpur, 2010.

Zakariya, Hafiz. "Colonialism, Society and Reforms in Malaya: A Comparative Evaluation of Shaykh Tahir Jalaluddin and Syed Shaykh Ahmad al-Hady." Intellectual Discourse (2017), 477-501.

Zakariyya, Hafiz. "Islamic Reform in Malaya: The Contribution of Shayk Tahir Jalaluddin." Intellectual Discourse, vol. 13, no. 5 (2005), 49-72.

Zakariyya, Hafiz. "The Life and Times of Tahir Jalaluddin." Jurnal Sejarah, vol. 14 (2006), 89-116. 
Jurnal Fiqh, Vol. 16 No. 2 (2019) 289-320 